\title{
US State Economic Freedom and the Labor Supply of Young Workers
}

\author{
Jeffrey J. Yankow \\ Department of Economics, Furman University, Greenville, SC, USA \\ Email: jeff.yankow@furman.edu
}

Received 25 May 2016; accepted 18 July 2016; published 21 July 2016

Copyright (C) 2016 by author and Scientific Research Publishing Inc.

This work is licensed under the Creative Commons Attribution International License (CC BY). http://creativecommons.org/licenses/by/4.0/

c) (i) Open Access

\begin{abstract}
Matching panel data drawn from the National Longitudinal Survey of Youth 1979 to the state-level index of economic freedom published in Economic Freedom of North America 2010, this study examines the empirical relationship between the degree of economic freedom in US states and individual labor supply. OLS estimation identifies a positive correlation between economic freedom and annual hours worked. However, this relationship disappears when the model accounts for time-invariant person-specific fixed effects. Although states with higher degrees of economic freedom appear to generate higher productivity and therefore labor earnings potential among workers, most workers do not increase their hours of work in response.
\end{abstract}

\section{Keywords}

Labor Supply, Economic Freedom, Wages, Earnings

\section{Introduction}

There is a voluminous literature exploring the relationship between economic freedom and prosperity across nations. Cross-country studies have tended to focus attention on aggregate variables of economic performance such as rates of economic growth. For example, Sturm and De Haan [1], Cole [2], Gwartney [3], and Cebula and Clark [4] demonstrate that countries with more economic freedom are associated with higher rates of economic growth. But even within nations there is often considerable variation in economic freedom across sub-national jurisdictions, such as the individual states within the United States of America.

State-level economic policies such as taxation, government spending, and business regulation have been shown to have important relationships with a multitude of measures of state economic performance. For example, Tomljanovich [5] shows that higher state tax rates reduce state economic growth over time. Both Crain and Lee [6] and Garrett, Wagner, and Wheelock [7] present evidence that states with a smaller government share of 
gross state product show greater rates of income growth, while Conway [8] demonstrates that greater public sector spending generates a significant reduction in labor supply by workers within the state. McPhail, Orazem, and Singh [9] find that state tax policies have a meaningful impact on state-level labor productivity.

Because US states continuously adjust economic policies along a variety of dimensions, researchers have begun to turn their attention to more comprehensive measures of the overall institutional environment of each state. Indeed, researchers have already explored how state-level measures of economic freedom correlate with many important economic outcomes, such as employment growth [10], migration [11] [12], income inequality [13], investment [14], and entrepreneurship [15]. One relationship that has received little empirical scrutiny to date, however, is that between state-level economic freedom and individual labor supply.

Why might the degree of economic freedom affect individual labor supply decisions? As the size of government increases, individuals may have less opportunity to benefit from private enterprise. For example, Conway [8] demonstrates that public sector spending has an important negative influence on male labor supply. Her results suggest that a \$100 increase in per capita public spending results in a 13- to 14-hour reduction in labor supply per year. ${ }^{1}$ A greater tax burden may reduce the private consumption and/or investment benefits that result from greater labor supply. Additionally, more restrictive labor markets may make it more difficult for employers and workers to negotiate mutually-beneficial outcomes.

One of the more convenient and useful measures of a state's institutional environment is the index of economic freedom for US states (and Canadian provinces) found in the Economic Freedom of North America report published regularly by the Frasier Institute, an independent Canadian public policy and educational organization. The sub-national economic freedom index attempts to evaluate the degree to which individual state and local governments protect private property and allow markets to operate with minimal government interference. Matching an extended panel of data drawn primarily from the National Longitudinal Survey of Youth 1979 to the state economic freedom indices contained in the Fraser Institute's Economic Freedom of North America 2010 [16], this study examines how state economic freedom affects the annual labor supply of young workers. Because workers in the dataset can be tracked over more than two decades, this study also examines the relevance of changes in state-level public policy over time. In this case the length of the panel is important because the level of economic freedom in each state tends to be similar in proximal years, but often exhibits large differences within a state over long periods. Moreover, the longitudinal aspect of the data is exploited to control for issues of simultaneity and selection that may plague earlier studies on the relationship between government policy and employment outcomes at the state level.

\section{Data}

The National Longitudinal Survey of Youth 1979 (NLSY79) provides a comprehensive data set well suited for the study of labor supply. Beginning with an original cohort of 12,686 men and women born between 1957-1964, the survey collected information on an annual basis from 1979 through 1994 and biennially thereafter. The work-history files contain information detailing the employment history of each respondent, including the annual hours contributed to market work.

The state-level economic freedom (SEF) indices utilized in this study are from Economic Freedom of North America 2010 [16]. The SEF index is constructed on a 10-point scale, with higher values denoting greater economic freedom, and is compiled from information at both the state and local level of government. The index evaluates economic freedom across three general areas of government intervention: the size of government, takings and discriminatory taxation, and labor market freedom. ${ }^{2}$ Each of these three areas also has its own freedom index, and the overall SEF index is an equally-weighted average of the three areas. Each economic freedom index score for a particular state is relative to that of all other states by construction. More importantly for purposes of this study, the index is also consistent over time. The index covers the years 1981 through 2007.

In order to generate a sample suitable for empirical analysis, several selection criteria were introduced. First, I restrict the analysis to men in order to avoid issues related to intermittent labor force participation. Second, I re-

\footnotetext{
${ }^{1}$ Unmarried women show the same pattern as men, though married women show no effect.

${ }^{2}$ The "size of government" area evaluates general consumption expenditures by government as a percentage of GDP, transfers and subsidies as a percentage of GDP, and social security payments as a percentage of GDP; the "takings and discriminatory taxation" area evaluates total government revenue from own source as a percentage of GDP, the top marginal income tax rate and the income threshold at which it applies indirect tax revenue as a percentage of GDP, and sales taxes collected as a percentage of GDP; the "labor market freedom" area evaluates minimum wage legislation, government employment as a percentage of total state employment, and union density.
} 
strict the analysis to the period 1980 through 2000. Finally, I require valid data for all variables used in the estimation, except the Armed Forces Qualifying Test (AFQT). Introducing these selection criteria produced a sample of 4398 men contributing a total of 27,167 person-year observations.

The key variables in the ensuing empirical analysis are annual hours worked and annual labor earnings. The measure of annual hours worked is generated from the weekly hours array contained in the NLSY79 work-history data files. The work-history file contains the usual hours worked each week on all jobs for each respondent starting from the first week in January 1978 and running through the final interview week. Annual hours worked are then calculated by summing over all weeks in each calendar year for which a complete data file present. The measure of annual labor earnings was created from the questions regarding all labor earnings in the previous calendar year. Hours and earnings for each calendar year were then linked to the geocode data from the previous interview date so that information on the state of residence is contemporaneous with both calendar-year hours and earnings. ${ }^{3}$

Other regressors include the race (black, Hispanic) and age of the respondent. The highest grade completed is used as a proxy for the education level. Household characteristics include whether the respondent is married with the spouse present in the household and the number of children in the household. To capture individual differences in the ability to acquire skills, I use the score from the AFQT. The score used in the empirical analysis is adjusted for the age at which the respondent took the test. Location characteristics include whether the respondent lives in a non-rural area, the state unemployment rate, and the state poverty rate. Summary statistics for each of the variables are provided in Table 1.

\section{Estimation Strategy}

Consider the following general model:

$$
y_{i t}=\alpha_{i}+S E F_{i t} \delta+X_{i t} \beta+\varepsilon_{i t}
$$

Here $y_{i t}$ is a measure of labor market outcomes for individual $i$ in year $t$. The primary dependent variable used in the empirical analysis is the natural logarithm of annual hours worked (plus one). I use the natural log of hours for easier interpretation of the estimated coefficients of the model. Besides annual hours, the natural log of annual labor income and the log of the reported hourly wage are also used as alternative dependent variables. The individual's observable characteristics at time $t$ are given by $X_{i t}$. White noise is accounted for by random disturbance $\varepsilon_{i t}$.

\begin{tabular}{ccc} 
Table 1. Summary statistics. & & \\
\hline Variables & Mean & Standard deviation \\
\hline Annual hours worked $^{\text {Annual labor earnings }}{ }^{\mathrm{a}}$ & 2079.7 & 754.0 \\
Hourly wage $^{\mathrm{a}}$ & $23,824.5$ & $18,407.4$ \\
Annual net non-labor income $^{\mathrm{a}}$ & 11.2 & 15.1 \\
Black & $18,191.3$ & $60,862.0$ \\
Hispanic & 0.252 & 0.434 \\
Highest grade completed & 0.211 & 0.408 \\
Age & 12.869 & 2.354 \\
Normalized AFQT score & 28.131 & 5.704 \\
AFQT missing & 3.651 & 28.683 \\
Married, spouse present & 0.042 & 0.202 \\
Number of children & 0.441 & 0.496 \\
Resides in non-rural area & 0.700 & 1.068 \\
State unemployment rate & 0.913 & 0.282 \\
State poverty rate & 6.830 & 2.063 \\
SEF index & 12.702 & 2.904 \\
Observations & 6.909 & 0.902 \\
Individuals & 27,167 & \\
\hline
\end{tabular}

${ }^{\mathrm{a}}$ Measured in 1990 US dollars.

${ }^{3}$ This structure was chosen because the majority of surveys were conducted during summer months. Consequently, if migrations occur midway between interviews, on average, the calendar year will most accurately reflect the correct state of residence. 
Two alternative specifications are used to test the relationship between state economic freedom and labor supply: OLS models, in which the intercept is constrained to be equal for all individuals ( $\alpha_{i}=\alpha$ for all $i$ ) and fixed-effects models, in which the intercept is allowed to vary across individuals but not over time.

In developing the baseline specifications for annual hours worked, it is not clear whether wage or income information should be included in the model due to concerns about endogeneity. For this reason, Rosenthal and Strange [17] advocate a reduced-form model that omits any measure of the worker's wage from the specification, especially in instances when an hourly wage is measured imprecisely. In contrast, Conway [8] argues for the necessity of including the hourly wage as well as a measure of non-labor income when examining individual labor supply. I follow the latter approach and include measures of the hourly wage and annual net non-labor income. Although the estimated coefficients on the wage and income variables are likely biased, it should allow for a cleaner estimate of the impact of SEF on the choice of hours.

\section{Empirical Results}

\subsection{Hours Worked}

Table 2 reports the main estimation results starting with the OLS estimates in column (1). The coefficient estimate on the state economic freedom variable is 0.016 and statistically significant at the five-percent level, suggesting that workers living in states with high economic freedom scores tend to work longer hours.

Why might this be the case? There are at least two possible explanations.

One possibility is that more economic freedom may encourage workers to choose longer hours because their work is more productive and therefore better rewarded. For example, greater labor market freedom may make it easier for employers and workers to negotiate mutually-beneficial outcomes. If greater economic freedom increases the quality of the job matches within a state, then both income and hours worked will affected. If the substitution effect is relatively large, the greater compensation will encourage more labor supply.

Alternatively, naturally-motivated workers may be drawn to states with high degrees of economic freedom because the rewards to hard work are higher (since they will get to keep more of what they make, for example). In this case, economic freedom doesn't actually raise labor supply but rather dynamic selection concentrates workers with exogenously high labor attachment in those states with high economic freedom scores.

In an effort to distinguish between competing hypotheses, I estimate the baseline model controlling for a time-

Table 2. Effect of state economic freedom index on (ln) annual hours worked.

\begin{tabular}{ccc}
\hline Variable & OLS $(1)$ & Fixed effects $(2)$ \\
\hline SEF index & $0.016^{\mathrm{b}}(0.007)$ & $-0.023(0.015)$ \\
Ln hourly wage & $0.147^{\mathrm{a}}(0.014)$ & $0.041^{\mathrm{b}}(0.017)$ \\
Ln annual net non-labor income & $-0.013^{\mathrm{a}}(0.001)$ & $-0.013^{\mathrm{a}}(0.001)$ \\
Black & $-0.081^{\mathrm{a}}(0.016)$ & \\
Hispanic & $-0.028(0.015)$ & \\
Age & $0.011^{\mathrm{a}}(0.003)$ & $0.152^{\mathrm{a}}(0.008)$ \\
Highest grade completed & $0.118^{\mathrm{a}}(0.012)$ & $0.041^{\mathrm{b}}(0.021)$ \\
Age squared (×10) & $-0.019^{\mathrm{a}}(0.002)$ & $-0.013^{\mathrm{a}}(0.002)$ \\
Normalized AFQT score & $-0.000(0.000)$ & \\
AFQT missing & $0.017(0.022)$ & \\
Married, spouse present & $0.180^{\mathrm{a}}(0.013)$ & $0.088^{\mathrm{a}}(0.015)$ \\
Number of children & $-0.008(0.006)$ & $-0.008(0.007)$ \\
Resides in non-rural area & $-0.023(0.016)$ & $0.011(0.024)$ \\
State unemployment rate & $-0.012^{\mathrm{a}}(0.004)$ & $-0.023^{\mathrm{a}}(0.005)$ \\
State poverty rate & $0.005^{\mathrm{b}}(0.002)$ & $0.002(0.005)$ \\
R-squared & 0.098 & 0.031 \\
\hline Observations & 27,167 & 27,167 \\
Individuals & 4398 & 4956 \\
\hline
\end{tabular}

Notes: Standard errors are in parentheses. Each model includes year dummies.

${ }^{\mathrm{a}}$ One-percent significance level; ${ }^{\mathrm{b}}$ Five-percent significance level.

\footnotetext{
${ }^{4}$ Results produced from models omitting the wage and income variables were qualitatively similar.
} 
invariant person-specific component (individual fixed effects). Assuming the fixed effect is the only component of the error term correlated with the measure of state economic freedom, purging the model of this term via fixed-effects regression techniques results in an unbiased parameter estimate. More specifically, if positive dynamic selection is important then controlling for the time-invariant fixed effect should cause estimates of the impact of SEF on annual hours worked to fall below the OLS estimates.

Looking at column (2) of Table 2, we see this to be the case. The coefficient on the state economic freedom index falls to -0.023 and fails to achieve statistical significance. Thus, it would appear that a correlation between unobserved time-invariant individual characteristics and the state economic freedom measure accounts for all of the positive relationship between SEF and hours worked identified in the OLS specification.

\subsection{Wages and Earnings}

There are at least two reasons to think that the degree of state economic freedom would also affect wages and earnings. First, if a high degree of economic freedom affects preferences toward work, one might see an increase in work effort (and therefore productivity) conditional on hours worked (as well as an increase in hours worked). Second, greater economic freedom may increase the quality of the job matches within a state.

I first estimate a model with the natural log of annual income as the dependent variable with annual hours worked as an included regressor. The results are reported in columns (1) and (2) of Table 3. The OLS estimate of the SEF coefficient is 0.010 and statistically insignificant. This suggests that workers in states with high degrees of economic freedom are no better paid than workers in low economic freedom states.

If dynamic positive selection of high "ability" workers into high economic freedom states is driving this result, then we would expect to see a result similar to what we found with the fixed-effect specification for the annual hours worked equation, namely a reduction in the coefficient estimate on state economic freedom. The fixedeffects estimation results are shown in column (2) of Table 3. The point estimate on the state economic freedom measure is 0.047 and now highly significant at the one-percent level. Somewhat surprisingly, this result suggests a negative correlation between the individual fixed effect and state economic freedom in the earnings equation.

As a robustness check, I re-estimate the model using the natural log of the hourly wage reported by respondents for their CPS-designated job in the NLSY79. The OLS and fixed-effect estimation results are presented in columns (3) and (4) of Table 3, respectively. The estimates from the wage equation mirror those produced by the annual earnings model with the coefficient estimate on the state economic freedom measure again rising af-

Table 3. Effect of state economic freedom index on (ln) earnings and wages.

\begin{tabular}{|c|c|c|c|c|}
\hline \multirow{2}{*}{ Variable } & \multicolumn{2}{|c|}{ Ln annual labor earnings } & \multicolumn{2}{|c|}{ Ln hourly wage } \\
\hline & OLS (1) & Fixed effect (2) & OLS (1) & Fixed effect (2) \\
\hline SEF index & $0.010(0.014)$ & $0.047^{\mathrm{a}}(0.013)$ & $0.013(0.010)$ & $0.057^{\mathrm{a}}(0.009)$ \\
\hline Ln annual hours worked & $0.581^{\mathrm{a}}(0.021)$ & $0.436^{\mathrm{a}}(0.006)$ & $0.061^{\mathrm{a}}(0.006)$ & $0.013^{\mathrm{a}}(0.004)$ \\
\hline Black & $-0.140^{\mathrm{a}}(0.021)$ & & $-0.078^{\mathrm{a}}(0.015)$ & \\
\hline Hispanic & $-0.014(0.021)$ & & $-0.036^{\mathrm{b}}(0.016)$ & \\
\hline Highest grade completed & $0.051^{\mathrm{a}}(0.004)$ & $0.176^{\mathrm{a}}(0.005)$ & $0.039^{\mathrm{a}}(0.003)$ & $0.080^{\mathrm{a}}(0.004)$ \\
\hline Age & $0.246^{\mathrm{a}}(0.013)$ & $0.168^{\mathrm{a}}(0.015)$ & $0.117^{\mathrm{a}}(0.008)$ & $0.080^{\mathrm{a}}(0.010)$ \\
\hline Age squared (×10) & $-0.033^{\mathrm{a}}(0.002)$ & $-0.029^{\mathrm{a}}(0.002)$ & $-0.014^{\mathrm{a}}(0.002)$ & $-0.014^{\mathrm{a}}(0.001)$ \\
\hline Normalized AFQT score & $0.003^{\mathrm{a}}(0.000)$ & & $0.003^{\mathrm{a}}(0.000)$ & \\
\hline AFQT missing & $-0.030(0.034)$ & & $-0.021(0.026)$ & \\
\hline Married, spouse present & $0.277^{\mathrm{a}}(0.014)$ & $0.150^{\mathrm{a}}(0.011)$ & $0.163^{\mathrm{a}}(0.011)$ & $0.110^{\mathrm{a}}(0.008)$ \\
\hline Number of children & $-0.001(0.007)$ & $-0.013^{\mathrm{b}}(0.006)$ & $0.007(0.005)$ & $0.002(0.004)$ \\
\hline Resides in non-rural area & $0.052^{\mathrm{b}}(0.021)$ & $0.046^{\mathrm{b}}(0.019)$ & $0.041^{\mathrm{a}}(0.015)$ & $0.012(0.013)$ \\
\hline State unemployment rate & $-0.008(0.005)$ & $-0.011^{\mathrm{a}}(0.003)$ & $0.000(0.003)$ & $-0.000(0.002)$ \\
\hline State poverty rate & $-0.012^{\mathrm{a}}(0.004)$ & $-0.011^{\mathrm{a}}(0.004)$ & $-0.012^{\mathrm{a}}(0.003)$ & $-0.008^{\mathrm{a}}(0.003)$ \\
\hline R-squared & 0.511 & 0.409 & 0.319 & 0.251 \\
\hline Observations & 27,167 & 27,167 & 27,167 & 27,167 \\
\hline Individuals & 4398 & 4398 & 4398 & 4398 \\
\hline
\end{tabular}

Notes: Standard errors are in parentheses. Each model includes year dummies and US census division dummies.

${ }^{a}$ One-percent significance level; ${ }^{b}$ Five-percent significance level. 
ter accounting for individual fixed effects.

The estimation results from the wage models suggest two important things. First, work appears to be better rewarded in states with high degrees of economic freedom. Second, workers with exogenously low potential earnings appear to be concentrated in states with high degrees of economic freedom.

The negative correlation between the individual fixed effect and state economic freedom identified in the wage and earnings equations casts grave doubt on the hypothesis of positive dynamic selection into high economic freedom states. Yet if workers are generally more productive in high economic freedom states, then why do we see increased hours only concentrated among those with exogenously high effort or ability?

One possible explanation may relate to hours constraints faced by workers in low wage jobs. Kahn and Lang [18] report that about half of the workforce in their sample would prefer to work a different number of hours than their actual experience. More importantly, holding the hourly wage constant, they find that the majority of these workers would prefer to work longer hours. Rosenthal and Strange [17] also find some evidence of workspreading among non-professional workers in urban areas. If employers tend to channel "additional" hours only toward their most productive workers, this could conceivably account for the fixed-effects results in the hours equation. In this case, all workers in high economic freedom states would generally prefer to work greater hours, but only a limited amount of extra hours are made available to the highest productivity workers. Another possibility is that one or more of the models estimated in this study are incorrectly specified in some important way.

\section{Conclusions}

This research attempts to shed some light on the complex relationship between hours, income, and economic freedom. Although OLS estimation identifies a positive correlation between economic freedom and hours worked, this relationship disappears when the model accounts for time-invariant person-specific fixed effects. A plausible explanation appeared to be dynamic selection in which workers with strong labor force attachment are attracted to states with high degrees of economic freedom.

The results from income and wage equations do not corroborate this story. Fixed-effects estimates from both annual labor earnings and wage equations identify a negative correlation between the fixed effect and the index of state economic freedom. Nevertheless, a positive relationship between state economic freedom and labor earnings remains. Although states with higher degrees of economic freedom appear to generate higher productivity and therefore labor earnings potential among workers, workers do not increase their hours of work in response to this increase.

\section{References}

[1] Sturm, J.E. and De Haan, J. (2001) How Robust Is the Relationship between Economic Freedom and Economic Growth? Applied Economics, 33, 839-844. http://dx.doi.org/10.1080/00036840121977

[2] Cole, J.H. (2003) The Contribution of Economic Freedom to World Economic Growth, 1980-99. Cato Journal, 23, 189-198.

[3] Gwartney, J.D. (2009) Institutions, Economic Freedom, and Cross-Country Differences in Performance. Southern Economic Journal, 75, 937-956.

[4] Cebula, R.J. and Clark, J.R. (2012) Lessons from the Experience of OECD Nations on Macroeconomic Growth and Economic Freedom, 2004-2008. International Review of Economics, 59, 231-243. http://dx.doi.org/10.1007/s12232-012-0162-0

[5] Tomljanovich, M. (2004) The Role of State Fiscal Policy in State Economic Growth. Contemporary Economic Policy, 22, 318-330. http://dx.doi.org/10.1093/cep/byh023

[6] Crain, W.M. and Lee, K.J. (1999) Economic Growth Regressions for the American States: A Sensitivity Analysis. Economic Inquiry, 37, 242-257. http://dx.doi.org/10.1111/j.1465-7295.1999.tb01428.x

[7] Garrett, T.A., Wagner, G.A. and Wheelock, D.C. (2007) Regional Disparities in the Spatial Correlation of State Income Growth, 1977-2002. Annals of Regional Science, 41, 601-618. http://dx.doi.org/10.1007/s00168-007-0114-x

[8] Conway, K.S. (1997) Labor Supply, Taxes and Government Spending: A Microeconometric Analysis. Review of Economics and Statistics, 79, 50-67. http://dx.doi.org/10.1162/003465397556539

[9] McPhail, J.E., Orazem, P. and Singh, R. (2010) The Poverty of States: Do State Tax Policies Affect State Labor Productivity? Iowa State University, Working Paper 10010.

[10] Garrett, T.A. and Rhine, R.M. (2010) Economic Freedom and Employment Growth in U.S. States. Research Division, 
Federal Reserve Bank of St. Louis, Working Paper Series 2010-006A.

[11] Ashby, N. (2007) Economic Freedom and Migration Flows between U.S. States. Southern Economic Journal, 73, 677697.

[12] Cebula, R.J. and Clark, J.R. (2011) Migration, Economic Freedom, and Personal Freedom: An Empirical Analysis. Journal of Private Enterprise, 27, 43-62.

[13] Ashby, N.J. and Sobel, R.S. (2008) Income Inequality and Economic Freedom in the U.S. States. Public Choice, 134, 329-346. http://dx.doi.org/10.1007/s11127-007-9230-5

[14] Dawson, J.W. (1998) Institutions, Investment, and Growth: New Cross-Country and Panel Data Evidence. Economic Inquiry, 36, 603-619. http://dx.doi.org/10.1111/j.1465-7295.1998.tb01739.x

[15] Kreft, S. and Sobel, R. (2005) Public Policy, Entrepreneurship, and Economic Freedom. Cato Journal, 25, 595-616.

[16] Ashby, N., Karabegovic, A., McMahon, F. and Bueno, A. (2010) Economic Freedom of North America: 2010 Annual Report. The Fraser Institute, Vancouver.

[17] Rosenthal, S.S. and Strange, W.C. (2008) Agglomeration and Hours Worked. Review of Economics and Statistics, 90, 105-118. http://dx.doi.org/10.1162/rest.90.1.105

[18] Kahn, S. and Lang, K. (1991) The Effect of Hours Constraints on Labor Supply Estimates. Review of Economics and Statistics, 73, 605-611. http://dx.doi.org/10.2307/2109399

\section{Submit or recommend next manuscript to SCIRP and we will provide best service for you:}

Accepting pre-submission inquiries through Email, Facebook, LinkedIn, Twitter, etc.

A wide selection of journals (inclusive of 9 subjects, more than 200 journals)

Providing 24-hour high-quality service

User-friendly online submission system

Fair and swift peer-review system

Efficient typesetting and proofreading procedure

Display of the result of downloads and visits, as well as the number of cited articles

Maximum dissemination of your research work

Submit your manuscript at: http://papersubmission.scirp.org/ 